\title{
Perspectives on Nicaragua's Foreign Trade
}

\section{Ian Goldin and Roberto Pizarro}

\section{Introduction}

The July 1979 revolutionary triumph of the Frente Sandinista Liberacion Nacional (FSLN) carried with it a promise to transform economic relations to the advantage of ordinary working people. The economy which the Sandinistas inherited was characterised by a dependence on agro-exports and a virtual absence of a domestic manufacturing base. It was a classical example of a peripheral, underdeveloped country, in which the growth of agro-exports reproduced the power of an oligarchy, undermining the position of the majority of the population.

The Sandinistas' revolutionary programme was premised on a continuing foreign exchange requirement. Imported basic foodstuffs, medicines, tractors and thousands of other imported items were integral to the transformation of social relations. Furthermore, commitments to electrification and the expansion of transport and agricultural services presupposed a supply of fuel and capital good imports. The nature and origin of imports changed with the revolution, but the dependence on imports continued; the FSLN from the outset implicitly recognised that economic isolationism would be followed by a collapse of the economy and a dramatic decline in living standards.

Notwithstanding the success of efforts to solicit loans and aid, agro-exports remained the principal source of foreign exchange. In this sense, coffee, cotton, sugar and bananas were as important in securing the FSLN economic base as these agro-exports had been to successive Somoza regimes. Yet the FSLN was only too aware that these agro-exports are characterised by destabilising price cycles, had been the economic base of the Somocista dictatorships and were rooted in exploitative labour systems. Not surprisingly, the question of foreign trade provided one of the greatest challenges facing the revolutionary government.

\section{Strategic Directions}

Between 1950 and 1977, a ninefold increase in agroexport production had provided the base for capital accumulation within Nicaragua. This accumulation was dependent on the state guaranteeing resources for the agro-export sector, at the expense of peasants and other members of the domestic agricultural sector.
Between 1950 and 1977 , the proportion of land devoted to food production fell from 75 per cent to 50 per cent and the domestic terms of trade moved sharply against domestic food producers [Gibson 1987:20]. Small food producers were consistently neglected by the state and excluded from the favourable credit, tariff and technical assistance programmes which pampered the development of agro-exports. By 1979, land, labour, technical inputs and other scarce resources had been directed towards production for the international market.

The main elements of the FSLN's post-revolutionary economic programme were outlined in their first major economic document - the 1980 'Plan for Reactivation for the Benefit of the People'. The objectives of the external sector were:

to initiate a programme to stimulate and increase the supply of revenue from the international market, while reorientating the utilisation of these revenues in the services of the people, and contributing to the process of eliminating all forms of workers' exploitation in the generation of these revenues [Ministerio de Planificación 1980].

The nationalisation of foreign trade and the banks was seen as a key which would provide the means to redistribute surplus away from the bourgeoisie. Simultaneouly, by gaining control of the foreign trade sector, the state was empowered to diversify trade and to rationalise imports in line with the new economic imperatives.

The continuing need for imports of food, fuel and other essentials meant that the reorganisation and rejuvenation of the structure of trade was given priority. Within the foreign trade sector, the abandonment or disruption of many essential tasks ${ }^{1}$ and the lack of Sandinista expertise in international commerce and finance posed a serious challenge for the new government. Almost overnight, a system which for decades had been controlled and staffed by an oligarchic private sector, was nationalised and

\footnotetext{
These being the jobs necessary to maintain exports, for example, contacts with buyers, monitoring of the markets, securing of contracts for sale and shipping, organising producers' deliveries, warehousing, quality control.

2 All traditional exports were nationalised. Non-traditional exports were largely left in private hands as were about 50 per cent of imports, but the state had a monopoly on disbursement of foreign currency.
} 
managed by the state. ${ }^{2}$ In an environment of uncertainty and destabilisation, the leadership set their immediate goal as the defence of existing exports.

The principle of non-alignment was central to the Sandinista programme. From the outset, the new government attempted to reflect this policy in its trade relations; it began to search for new markets and to reduce its historic dependence on the US. According to the 1980 plan, Nicaragua aimed to diversify its dependence.

Today, the aims of the foreign trade sector remain the maximisation of export earnings and the rationalisation of imports. These aims reflect an underlying pragmatism which recognises that Nicaragua is a small peripheral economy which is open to the world market and whose economy is heavily dependent on imported products. The foreign trade sector is responsible for improving export values and rationalising imports, while diversifying international economic relations and defending the economy from destabilisation, both as a result of commodity price falls and attempts by the USA to damage the Nicaraguan economy by attacking its foreign trade.

The experience of the past eight years has shown that the shortage of foreign exchange is a critical obstacle to the implementation of plans for economic development for the benefit of the mass of the population. In maximising export earnings, the state, while encouraging the longer term development of non-traditional exports, was dependent on improving the value and volume of traditional exports. Its initial goal was the recuperation of pre-revolutionary export levels. In rationalising imports, the aim was to seek better value and to diversify sourcing, while moving from imports of non-essential consumption goods to essential capital and productive items.

\section{Frustrated Ambitions}

The new direction in foreign trade in the year following the revolution was vindicated by a sharp improvement in export earnings. Subsequently, as Table 1 shows, there has been a virtually uninterrupted deterioration in foreign trade. This structural decline has advanced to the extent that trade imbalances now exercise a stranglehold, distorting the national economy, and providing one of the most intractable obstacles to the Sandinista revolution.

After hovering between $\$ 350$ and $\$ 500 \mathrm{mn}$ dollars in the period 1980 to 1984 , the trade deficit in 1985 grew to $\$ 593 \mathrm{mn}$ and $\$ 535 \mathrm{mn}$ in 1986 . Between 1977 and 1986 , the ratio of import to export values grew from 1.2 to $3.4 .^{3}$ The main causes of this crisis in foreign trade are outlined below.

\section{(a) International Finance}

At the time of the Sandinista victory, Nicaragua's foreign debt stood at about $\$ 1.6 \mathrm{bn}$, bolstered by a $\$ 65 \mathrm{mn}$ package provided by the IMF only five weeks before the collapse of the Somoza dictatorship. When the Sandinistas entered the Central Bank on 19th July 1979 , they found only $\$ 3 \mathrm{mn}$ in foreign currencies, barely sufficient to cover two days of imports [StahlerSholk 1987].

Over the period 1979 to 1983 , Nicaragua paid over $\$ 563 \mathrm{mn}$ in scheduled interest payments on the debts of the Somoza government, but received only $\$ 12 \mathrm{mn}$ in commercial bank finance (on 90 day terms). Debt servicing as a percentage of exports amounted to 16 per cent in 1980, 31 per cent in 1981 and 38 per cent in 1982,18 per cent in 1983 and about 28 per cent in 1984 [Stahler-Sholk 1987]. Despite these payments, the IMF refused to provide further finance, and after the election of Reagan, US finance ended in 1981, World Bank assistance in 1982 and Inter-American Development Bank funding in 1983. Despite the drying-up of commercial and multilateral credit, Nicaragua has managed to extend its trade deficit by strengthening its financial relations with Comecon, Latin American and certain Western European

${ }^{3}$ Ministerio Commercio Exterior (MICE), Managua.

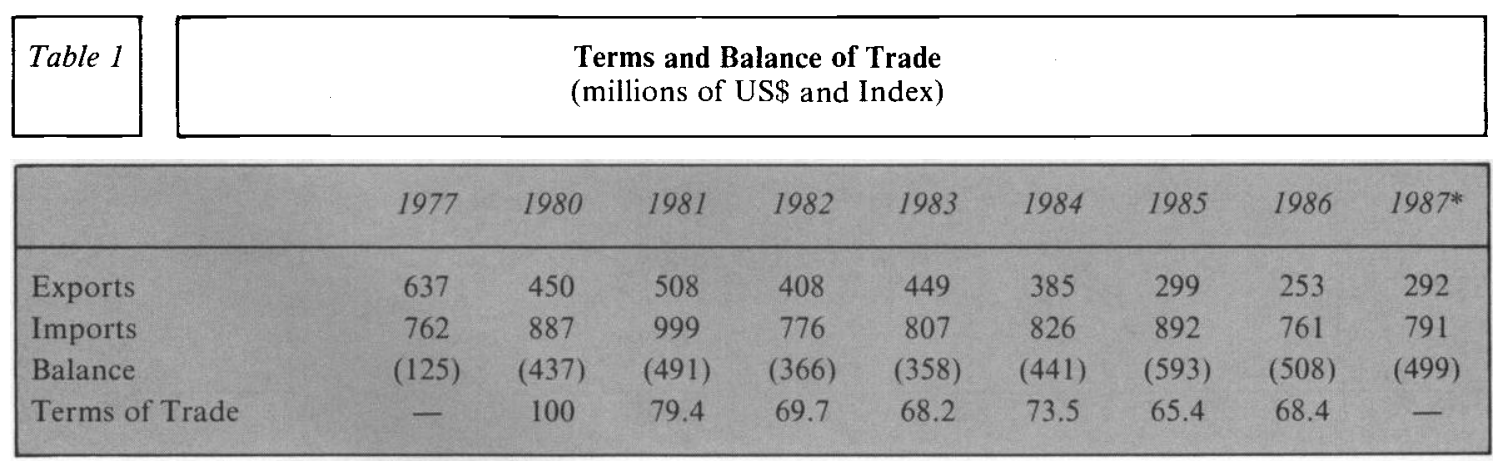

Source: Foreign Trade Ministry

* Preliminary 
countries. By the end of 1986 , the foreign debt burden exceeded $\$ 6$ bn.

The withering of multilateral financial assistance was associated with a decline in commercial bank credit for imports. Whereas in 1980, liquid credit accounted for 80 per cent of foreign imports, in 1986 less than 25 per cent of imports were paid for in convertible currency [MICE]. Faced by a mounting burden of debt, Nicaragua has been forced to rely increasingly on lines of credit, prefinancing, bilateral agreements and countertrade arrangements. Nicaragua's ability to maintain a trade deficit of over $\$ 500 \mathrm{mn}$ is testimony to its success in finding alternative sources of finance, enabling it to sustain import flows despite mounting US hostility. Nevertheless, non-convertible finance is a second-best option, which considerably restricts freedom to manoeuvre and, through prefinancing and other commitments, constrains export development. Moreover, of course, to the extent that the trade deficit is maintained, the debt burden is increased.

\section{(b) Terms and Patterns of Trade}

The deterioration of the trade balance and the associated growth in Nicaragua's burden of debt reflects the collapse of exports, rather than an undisciplined increase in imports. In 1986 the total value of imports was almost identical in nominal terms to 1977 import values. In real terms, therefore, there has been a marked decline in import values and volumes.

The extent to which Nicaragua has suffered from adverse terms of trade $^{4}$ is shown in Table 1. Between 1980 and 1986 , the terms of trade declined by 31.6 per

${ }^{4}$ Terms of trade $=$ trade (volume) weighted ratio of unit value of imports versus exports. cent. This decline roughly matches the growth in the trade deficit over the corresponding period, so that the widening of the trade deficit may largely be attributed to adverse price movements, rather than a growing imbalance between the volume of exports and imports.

The deterioration in the terms of trade has been accentuated by an increasing reliance on traditional exports and by the contraction of earnings from nontraditional exports from $\$ 134 \mathrm{mn}$ in 1977 to $\$ 29 \mathrm{mn}$ in 1986. As we shall see below, this contraction is due mainly to the decline in trade with countries of the Central American Common Market (CACM), which previously accounted for around 85 per cent of nontraditional exports (MICE). Table 2 shows that whereas in the period 1974-77 the CACM accounted for 23 per cent of Nicaragua's total trade flows, and in 1980 for 28 per cent, by 1986 it accounted for only 5 per cent. The USA's share of Nicaragua's total trade fell from 30.4 per cent in 1980 to nil in 1986. The share of Comecon countries, meanwhile, grew from 1 per cent to 39.4 per cent, while Western Europe's share rose from 17.6 per cent in 1980 to 35 per cent in 1986. Due mainly to the ending of Mexican and Venezuelan oil shipments, trade with the countries of the Latin American Economic Integration Association (ALADI), after increasing in importance, has returned to pre-revolutionary levels (MICE).

The rapid change in trading relations, and particularly the precipitous decline in trade with the USA, placed severe strains on the economy. As we show below, the US embargo compounded an already difficult situation. The embargo coincided with the escalation of the US-funded contra war and with a further deterioration in Nicaragua's terms of trade. Faced by this challenge, trade policies were adjusted to meet the

\begin{tabular}{|c|c|}
\hline Table 2 & $\begin{array}{c}\text { Diversification of Foreign Trade } \\
\text { (percentages) }\end{array}$ \\
\hline
\end{tabular}

\begin{tabular}{|lrrrrrr|}
\hline & $1974-77$ & 1980 & 1984 & 1985 & 1986 & $1987^{*}$ \\
\hline CACM & 22.8 & 28.1 & 9.2 & 6.8 & 5.3 & 5.4 \\
ALADI & 8.9 & 13.4 & 12.7 & 8.5 & 6.0 & 5.3 \\
Western Europe & 19.7 & 17.6 & 25.0 & 28.4 & 35.0 & 34.8 \\
USA & 28.2 & 30.4 & 14.9 & 7.3 & - & - \\
Japan & 9.8 & 3.1 & 9.9 & 7.7 & 5.8 & 4.4 \\
Canada & 0.8 & 2.6 & 2.9 & 1.6 & 3.1 & 1.7 \\
COMECON & 0.8 & 1.0 & 19.5 & 37.8 & 39.4 & 40.6 \\
Others & 9.0 & 3.8 & 5.9 & 1.9 & 5.4 & 7.8 \\
\hline Total & 100.0 & 100.0 & 100.0 & 100.0 & 100.0 & 100.0 \\
\hline
\end{tabular}

Source: Foreign Trade Ministry

* Preliminary 
new reality shaped by the embargo, contraction of commercial credit, the virtual collapse of the CACM and deteriorating terms of trade.

\section{(c) The Collapse of the Central American Common Market}

The withering of the Central American Common Market is evident from Table 3. Whereas in 1980 intra-regional trade was valued at $\$ 1,130 \mathrm{mn}$, by 1986 it had fallen to $\$ 370 \mathrm{mn}$, having contracted by twothirds in seven years. The decline of the CACM has particularly affected Nicaragua's non-traditional trade. In 1980, 88 per cent of Nicaragua's exports of industrial, manufactured and semi-processed products were destined for the region, while CACM countries supplied 44 per cent of Nicaragua's manufactured imports [SIECA 1987].

The deterioration in the political relations between Nicaragua and the other Central American countries is only part of the reason for the collapse of CACM. US financial assistance has supported the governments of US allies in the region, but has failed to arrest serious problems in the economies of Nicaragua's neighbours. Between 1981 and 1986, El Salvador's GDP declined by over 11 per cent and Guatemala's by 6 per cent. With Costa Rica's GDP expanding by 4 per cent, only Honduras, with a growth rate of 5.5 per cent, bettered Nicaragua's 5.0 per cent expansion in GDP. In per capita terms, Costa Rica's GDP fell 11 per cent, Honduras's 13.8 per cent, Nicaragua's 14.1 per cent, El Salvador's 16.7 per cent and Guatemala's 20.7 per cent [CEPAL 1987].

The shared problem of rapidly declining per capita GDP, in a context of declining terms of trade and the growing unevenness of the regional economy, has served to hasten the regional decline in trade. Intraregional trade imbalances have mounted to the extent where they frustrate further trade. Simultaneously, the exclusion of Nicaragua from the Caribbean Basin Initiative and the growing dependence of Nicaragua's neighbours on the US has undermined, but not destroyed, the commitment of Nicaragua's neighbours to the CACM. Esquipulas II is evidence of the failure of the US to isolate Nicaragua in the region. To the extent that this agreement signed by the Central American presidents is allowed to succeed, it will lead

\section{Table 3}

Exports and Imports

(percentages and millions of dollars)

\begin{tabular}{|l|cccc|rrrr|}
\hline & \multicolumn{4}{|c|}{ Exports } & \multicolumn{4}{c|}{ Imports } \\
\cline { 2 - 9 } & $1982-84$ & 1985 & 1986 & $1987^{*}$ & $1982-84$ & 1985 & 1986 & $1987^{*}$ \\
\hline Total & 100.0 & 100.0 & 100.0 & 100.0 & 100.0 & 100.0 & 100.0 & 100.0 \\
I. Third World & & & & & & & & \\
$\quad$ Countries & 22.6 & 16.6 & 10.3 & 10.6 & 40.8 & 23.2 & 18.9 & 20.7 \\
CACM & 10.0 & 8.1 & 6.1 & 7.1 & 13.1 & 6.4 & 5.0 & 4.8 \\
ALADI & 2.5 & - & 1.0 & 0.6 & 22.8 & 11.4 & 7.6 & 7.0 \\
Caribbean & 1.3 & 1.1 & 0.5 & 0.3 & 2.6 & 2.3 & 3.4 & 5.2 \\
Asia & 8.7 & 7.4 & 2.7 & 2.6 & 2.0 & 2.4 & 2.5 & 3.4 \\
Others & - & - & - & - & 0.3 & 0.7 & 0.4 & 0.3 \\
II. OECD & 68.6 & 78.2 & 71.8 & 58.3 & 40.9 & 33.3 & 34.7 & 33.9 \\
USA & 17.6 & 6.7 & - & - & 18.2 & 7.5 & - & - \\
$\quad$ EEC (12) & 30.5 & 47.0 & 52.2 & 44.8 & 14.9 & 16.6 & 19.3 & 22.7 \\
Others OECD & 20.5 & 24.4 & 19.6 & 13.4 & 7.9 & 9.2 & 15.3 & 11.2 \\
III. COMECON & 8.9 & 5.2 & 17.8 & 29.1 & 18.1 & 42.9 & 46.1 & 44.8 \\
IV. Others & - & - & 0.1 & 2.0 & 0.2 & 0.6 & 0.3 & 0.6 \\
Total Value & 407.2 & 298.5 & 253.0 & 292.0 & 802.9 & 892.3 & 761.0 & 791.0 \\
\hline
\end{tabular}

Source: Foreign Trade Ministry

* Preliminary 
to a renewed commitment to intra-regional trade.

\section{(d) US Commercial Hostility and the Embargo}

At the time of the Sandinista victory, the foreign trade sector was even more dependent on the USA than the aggregate statistics suggest. In the period, 1974 to 1977 , the US accounted for 28 per cent of all foreign trade (approximately 30 per cent of imports and 26 per cent of exports according to MICE). The dependence on the US market was particularly acute in the case of sugar, bananas, shellfish, meat and tobacco, as virtually all Nicaragua's exports of these products were destined for the US market.

In the case of bananas, meat and shellfish, the dependence on the US stemmed from the geographical proximity to the market and, in the case of bananas, to the complete control of the sector by the Standard Fruit Company. Sugar's development in the 1960 s was premised on US preferential prices and followed from the suspension of US purchases of Cuban sugar after Castro's victory. After helping the US in its aborted attempt to overthrow Castro, Somoza was rewarded with an agreement for preferential sugar sales to the US. In May 1983, the US again used political criteria, but this time to reduce Nicaragua's quota by 90 per cent and, after vetoing financial multilateral aid to Nicaragua, in May 1985 to implement a full trade embargo.

Although the US was insignificant as a market for cotton and in 1982 accounted for only 5 per cent of coffee exports, the processing of cotton and coffee products into an exportable form (including soluble coffee and cotton lint) was dependent on US machinery, spare parts and maintenance. All export sectors were also almost totally dependent on imports from the US for tractors, harvesting equipment, fertilisers, pesticides and other production inputs, and for the maintenance of warehousing, transport and port facilities.

US hostility against Nicaragua has taken many forms. Support for the contras is only one element; the attempt to isolate Nicaragua economically and politically, and to ruin the economy, is another. The foreign trade sector has not escaped dislocation. The disruption of exports has served to tighten the foreign exhange noose and exacerbate domestic economic disequilibrium. In terms of direct commercial losses, the cost of the embargo from May 1985 to December 1986 has exceeded $\$ 200 \mathrm{mn}$. To this must be added the costs resulting from the rapid withdrawal of the Standard Fruit in October 1982, the 90 per cent reduction in the quota for sales of sugar to the US in May 1983 and the 1983 mining of Corinto harbour (MICE).

\footnotetext{
5 Ministerio de Desarrollo Agropecuario y Reforma Agraria (MIDINRA).
}

Despite the enormous cost of the embargo, it did not have the desired effect of destroying the Nicaraguan economy. Within a remarkably short time, Nicaragua found new markets for the products previously sold in the USA. However, even where the delivered prices were equivalent to those in the US market, Nicaragua has suffered a loss as a result of having to ship over a greater distance. These transport costs are particularly important in the case of perishables, such as shellfish, meat and bananas, which before the embargo went to the USA. Furthermore, while the value to Nicaragua of sales to European and Far Eastern markets is diminished by transport costs, the need to rely on these more distant locations for imports has inflated import values. Meanwhile, the move away from dollar purchases to Yen, D-Mark and other currencies has meant that Nicaragua has been particularly vulnerable to the appreciation of the major EEC and Far Eastern currencies against the US dollar, as virtually all Nicaragua's exports are valued in dollars.

Nicaragua's agility in diversifying its markets meant that the embargo had mainly a short-term direct impact on exports. In the longer term, the impact of the embargo on imports and its consequent indirect impact on exports is much more serious. Until 1979, almost all investment and infrastructural development in Nicaragua included US machinery and equipment. The fact that spare parts and replacements are no longer available has seriously undermined virtually every capital input which predates 1979. For example, tractors, harvesters and crop processors are idle or inefficient for want of spare parts; electricity supplies are threatened by the breakdown of ageing US generators; doctors and dentists cannot get replacement parts for their equipment; US-made cars, trucks and buses are falling apart ... all sectors are affected by shortages of US equipment, and, with wear and tear, the list is extending daily.

The embargo has been in force for over two years and its impact on the infrastructure is becoming more and more apparent. Despite Nicaragua's ingenuity in devising substitutes, the impact of the embargo is reflected in the decay of capital goods and machinery manufactured in the US. The cost of this infrastructural decay has been estimated easily to exceed the direct impact of the embargo on foreign trade. Moreover, by undermining the productive and processing capacity of the agro-export sector, the indirect impact of the embargo on export earnings is more serious than the direct loss resulting from the end of US purchases of Nicaragua products.

\section{(e) The Contra War}

The contra war is the single most important factor accounting for the collapse of the Nicaraguan economy [FitzGerald 1987]. The ending of the war and the US embargo on trade and multilateral lending 
is a prerequisite for economic stabilisation and growth. This would lead to an improvement in export unit values, both as a result of reduction in transport costs and quality improvements. Improvements in quality would take place at all levels, starting from availability of better pesticides (in the case of cotton) to improvements in processing, where shortages of spare parts, chemicals and other inputs has led to a deterioration of quality.

Higher export volumes may be expected to result from the rehabilitation of farmlands in the war zones. Of the agro-exports, coffee has been most directly affected by the war. The highlands bordering Honduras are the location of prime coffee plantations, and the restoration of this production will add to coffee export volumes. Export values would simultaneously be improved, as coffee from Segovia and nearby provinces is among the best in Central America.

Agro-exports which are not located in the war zones have experienced numerous war-related problems, which have led to declines in volumes and yields. The necessary prioritisation of the military has meant that at times agricultural production and quality has suffered from a lack of transport for inputs and for exports. Production has also suffered due to the mobilisation of workers, including many of the most skilled and able technicians and administrators.

In production, attempts to diversify have been directly and indirectly frustrated by the war. A large oil-palm project on the Atlantic Coast - designed to end reliance on imported vegetable oil - has been set back, as have projects to exploit the potential of a number of remote mines. Furthermore, small-scale projects, such as those attempting to take advantage of the potential for growing valuable herbs and spices in the mountain regions, have been frustrated by lack of resources and the danger in these remote regions posed by the contra, for whom, agricultural development projects are a prime target.

\section{(f) Internal Policy}

The FSLN accepted from the outset that their need for foreign exchange meant a continued reliance on agroexports. However, the nature of the balance between agro-exports and domestic food crops, and the content of agro-export development remains a subject of discussion to this day.

In the first years after the revolution, agricultural development tended to be directed towards large, capital-intensive projects. The nationalisation of Somocista and abandoned lands facilitated the rapid development of state farms and large collectives, while the willingness of donors to support big projects skewed agricultural development towards aid-sponsored landmarks. These projects were viewed as nodes of development in which advanced agricultural technologies would overcome underdevelopment [Arguello and Kleitap 1985:4; Pizarro 1987].

Outside these nodes of development, agricultural policy largely failed to stimulate agro-exports and, to a lesser extent, food production. This failure was due in large part to inadequate producer prices and growing distortions within the system of agricultural pricing. Until 1985, the government aimed to stimulate production by the provision of cheap credit and inputs. Simultaneously, however, producer prices were held down, so that the whole cost structure of the agricultural sector was undervalued; the cost of this was reflected in increasing subsidies and a mounting fiscal deficit. Meanwhile, the overvaluation of the cordoba provided producers with remarkably cheap inputs, but also meant that agro-export prices failed to reflect world prices.

Until 1985, subsidies limited urban price increases, and the rigidity of producer prices and the exchange rate undermined the profitability of agricultural production. By 1984, the resulting fiscal and trade deficit and the mushrooming of a secondary informal market had increased the pressure for reform. However, by this time the contra war had undermined the potential for stabilisation and the 1985 devaluation of the cordoba, reduction in subsidies and raising of producer prices served to slow, but not end, the downward spiral. In the subsequent two years, government-determined producer prices and exchange rates attempted to track the hyperinflated and rapidly devaluing cordoba. This together with the introduction of dollar incentives for the principal agro-exports, prevented a further slide in agricultural production, but proved inadequate in containing the war-driven hyperinflation.

\section{Food versus Export Agriculture and Agrarian Reform}

The introduction of dollar incentives had rekindled old debates regarding the balance between export and food crops and the nature of agro-export production in the context of the Sandinista revolution. For many outside observers, the continued emphasis on agroexports appears to contradict the Sandinista agrarian reform programme and its commitment to food production and the end of exploitative labour systems. However, such an interpretation fails to recognise the limitations imposed on the Sandinistas by their requirement for foreign exchange. Furthermore, there is not a simple dichotomy between food and export crops; the challenge for the Sandinistas has been to explore the potential for the development of both food and export crops, in the context of changing social relations.

With the fall of the Somoza dynasty, the ending of coercive labour systems and the widespread distri- 
bution of credit and other agricultural inputs led to an immediate reduction in the migrant labour on which cotton, coffee and sugar harvesting depended. In addition, whereas previously Honduran and Salvadorian workers had participated in the coffee and cotton harvests, these migrants did not participate in the first harvest of the new Nicaragua. Within three months of coming to power, the Frente Sandinista was faced by a labour crisis that threatened to seriously disrupt agro-exports.

The government relied on the development of agricultural brigades from the urban areas to supplement the harvest labour force. In addition, attempts were made to raise the social wage within the agro-export sector (by providing health, schooling and other facilities). Finally, the development of state farms and agricultural cooperatives within the agroexport sector was seen as a way of meeting the aspirations of the peasantry without at the same time endangering the level of agro-exports. Agrarian reform and the development of cooperatives is central to the Sandinista attempt to transform rural social relations without the sacrifice of agro-export earnings. Far from being incompatible with agro-exports, agrarian reform is playing an increasingly important role in the development of the agro-export sector. In the coffee and cotton sectors, the development of cooperatives has provided the key to transforming social relations, while at the same time advancing the production of food and agro-exports.

Clearly, Nicaragua has not been able to transform cotton or coffee picking into a pleasant task. However, by diversifying agro-exports, extending mechanisation, staggering harvesting, developing harvesting brigades and establishing cooperatives which include both food and export crop production, Nicaragua has begun to move away from agro-export systems based on a marginalised and dispossessed peasantry. At the end of 1986, well over 25 per cent of arable land was farmed by agricultural cooperatives. These cooperatives accounted for 21 per cent of agro-exports and over 30 per cent of domestic food production.

\section{Conclusion}

The tension between food versus export crops is an inevitable result of the demand on the rural sector to meet different needs. In the short term, at least, there appear to be tensions between the allocation of land, labour, foreign exchange, managerial resources and products (for example, meat and sugar) between the export and domestic food sector. This tension parallels that between Marx's Department I and Department II and, is usefully examined in terms of the relationship between accumulation and consumption.

For peripheral countries, the generation of foreign exchange is vital for accumulation for growth and development. Nicaragua is almost entirely dependent on agro-exports for foreign exchange. This foreign exchange is essential for the transformation of Nicaragua's social relations and, not least, for the development of domestic food production. So, while agro-exports are necessary for the purchase of imports for food production, they also compete with food crops for scarce land and other resources. Projects aimed at reducing dependence on imported foodstuffs and raising domestic food consumption have been frustrated by the lack of foreign exchange and by the scarcity of domestic inputs [see Utting 1987]. In this context, attempts to develop self-sufficiency in grains, oilseeds, dairy products and other foods have been dependent on aid and often - at least in the short term - increase rather than diminish the requirement for foreign exchange, thereby placing more pressure on the agro-export sector.

The domestic availability of vegetable oil and dairy products is, of course, directly linked to the performance of the cotton and meat export sectors. Cottonseed oil is the only significant domestic source of vegetable oil, and any evaluation of the cotton sector needs to take this by-product into account. Similarly, it is impossible to examine the problem of dairy products in Nicaragua without taking into account the collapse of meat exports; as a result of cattle rustling and the premature slaughtering of herds, beef exports in 1983 were virtually half of their 1978 level. The sharp contraction of the exportoriented cattle sector was not only reflected in the trade statistics; it undermined the rural economy and ecology and led to a sharp decline in dairy products throughout the country.

In Nicaragua, as in similarly placed countries, the choice is not simply between food or export crops. Rather, it is a question of the resources allocated to each sector and the organisation of ownership and production. In practice, this requires an explicit recognition of the critical importance of agro-exports and the articulation of the foreign trade sector with the internal sector. This articulation takes place on all levels, so that it is as important to develop complementary food and agro-export harvesting systems, and to develop farming structures which are integral to the process of social transformation, as it is to develop balanced exchange rate and producer pricing policy.

Analyses which reproduce the naive, but nevertheless surprisingly pervasive dichotomy between food and export crops, are unhelpful. Countries like Nicaragua cannot hope to rid themselves of dependence on agroexports. To do so would be to condemn their population to total dependence on aid, and its associated strings, or to a return to near feudalism. There is no simple choice between food or export crop 
production. Rather, the challenge is to lessen the terms of dependence and to insulate the economy from the worst effects of dependence. Such strategies include a diversification of export products and markets, the rationalisation of imports and the development of a closer understanding of the dynamic between imports and exports and their economic and political significance. It is necessary to explore the tensions inherent in the existing world economic order as part of the struggle for a new economic order. On the international level, commodity agreements and the development of trade between developing countries provide some opportunities to take this struggle forward, while domestically agrarian reform and an end to exploitative labour practices provide another.

The priority for the foreign trade sector in Nicaragua, and for all other sectors of the economy, is the ending of the US-backed contra war. The end of the war and a lifting of the embargo should provide the springboard for a limited recovery of exports and for a redirection of imports to meet the development needs of a revolutionary country at peace. Clearly, such development will be severely constrained by the instability of the international commodity markets and the adverse and declining terms of trade for Nicaragua's traditional exports. The exploration of all avenues to diversify this dependence, to rationalise imports and to insulate the economy from commodity instability and adverse terms of trade remains a priority. It is unhelpful to insist that either food or agro-exports must come first. Both are essential to the Nicaraguan revolution.

\section{References}

Arguello, A. and Kleiterp, N., 1985, 'Analysis del proceso inversionista Nicaraguense de 1979 a 1985', Fondo Nacional de Inversiones, Managua (mimeo)

CEPAL, 1987, 'Balance Preliminar de la Economia Latino America 1986', Santiago

FitzGerald, E. V. K., 1987, 'An Evaluation of the Economic Costs to Nicaragua of U.S. Aggression: 1980-84', in R. Spalding (ed.), The Political Economy of Revolutionary Nicaragua, Allen \& Unwin, Boston

Gibson, B., 1987, 'A Structural Overview of the Nicaraguan Economy', in Spalding, $o p$. cit.

Ministerio de Planificación, 1980, 'Plan de Reactivacion Economica en Beneficio del Pueblo', Section II.4, Managua

Pizarro, R., 1987, 'The New Economic Policy: A Necessary Adjustment', in Spalding op. cit.

SIECA, 1987, El Comercio entro Americano en el Perido 1980-86, SEICA/ESC/87/01, Enero

Stahler-Sholk, R., 1987, 'Foreign Debt and Economic Stabilisation Policies in Revolutionary Nicaragua', in Spalding op. cit.

Utting, P., 1987, 'Domestic Supply and Food Shortages', in Spalding op. cit. 